\title{
Impact of Warana Co-Operative Complex on Standard of Living in Central Warana Basin of Southern Maharashtra, India ${ }^{1}$ Ramotra K. C. and ${ }^{2}$ Kanase.S.B.
}

\begin{abstract}
The present paper, mainly based on the primary data, attempts to analyze the standard of living of people in Central Warana Basin in parts of Kolhapur and Sangli districts of southern Maharashtra State. David Smith's ' $Z$ ' score method was employed for measuring the standard of living at village level by considering sixteen socio ecomic indices. It was assumed that nearer the village to the Warana co-operative complex higher is the standard of living. It is found that villages, Bahirewadi, Pargaon, Mohare, Talasande located near the complex, have shown high standard of living whereas the villages like Minche, Dongarwadi, Dewale, Pharnewadi are less developed. It is inferred that mostly the villages which are located near the complex are highly benefited in terms of economic development and those which are located away at a distance of 15 to $20 \mathrm{~km}$ are generally less influenced. The study suggests that the villages which are lagging behind in terms of the standard of living of people should be properly addressed to raise their standard of living by making provision of irrigation facilities and modern techniques in agricultural sector.

Keywords : standard of living, per capita income, pucca houses, gobar gas, irrigation facility
\end{abstract}

\section{Introduction}

The idea of standard of living
differs from person to person, from time to time and from place to place. However, ultimately the standard of living depends on one's level of income. The higher the income, the higher is the standard of living. When an individual's income is high, he will be accustomed to buy regularly most of the necessities, many comforts, and luxuries. On the other hand, when an individual's income is low, a major part of it is spent on the basic needs. If it is low, he may not be in a position to have even the most important necessaries of life. Hence those who get low income will have a low standard of living while others with high incomes will enjoy a higher standard of living. The Objectives of this study are to: assess the impact of Warana co-operative complex on the standard of living of the people in the region, and study the spatiotemporal changes in standard of living of the people in the study region. Based on two basic hypotheses that the nearer is the Methodology

The present paper is based on primary data collected by conducting intensive fieldwork in 12 out of 66 villages of command area of Warana co-operative sugar factory using well planned household schedules in the year 2004-05 through personal interview. The study region is divided into four concentric zones. Three villages from each concentric village to the Warana complex the higher the per capita income and standard of living and two, there is an inverse relationship between economic development and distance from the Warana complex. Villages located beyond the radius of 15 to $20 \mathrm{~km}$ are generally less influenced. The farther the distance between the inhabited villages and Warana co-operative complex the lesser is the economic development especially beyond the radius of $15-20 \mathrm{Km}$.

\section{Study Region}

The region undertaken for the present study is the command area of Warana cooperative sugar factory, Warananagar that falls in Kolhapur \& Sangli districts located in South-western part of Maharashtra State. It extends between $16^{0} 50^{\prime}$ north to $16^{\circ} 58^{\prime}$ north latitudes and $74^{0} 5^{\prime}$ east to $74^{0} 23^{\prime}$ east longitudes (see figure 1)

circle with radius of $5,10,15$ and $20 \mathrm{~km}$ from the site of Warana sugar factory have been selected for this purpose. Stratified sampling technique is used for the selection of villages and households in them.

The primary data collected through fieldwork and the secondary data from the Census of India reports, Tahsil office records and Talathi office. In order to

${ }^{1}$ Dept of Geography, Shivaji University,Kolhapur, Maharashtra,India

${ }^{2}$ Dept of Geography, Y.C.Warana Maha.Warananagar, Dist - Kolhapur, Maharashtra, India 
Compute the composite index for determining the standard of living of the people in the selected villages sixteen indices viz. literacy rate, female literacy rate, educational attainment with SSC, HSC, Graduation and above, work participation rate, proportion of workers in non-agriculture sector, land under irrigation, land holders having more than 2 ha of land, pucca houses, households having latrine facilities, households above three rooms, households having Gobar Gas/LPG facility, households having telephone facility, households having twowheelers (motor cycle, scooter, etc.) and per capita income were transformed into a single composite index for better comprehension by employing David Smith's ' $Z$ ' score method.
David Smiths Composite Index: = 'Z' score $=(\mathrm{x}-\mathrm{x}$ ')/SD

Where, ' $Z$ ' is composite index of the parameters $\mathrm{x}$ is a parameter of a sample village $\mathrm{x}^{-}$is an average value of the same parameters

SD is the standard deviation of the same parameters

Besides this, co-efficient of correlations between irrigation facilities and non-food crops, irrigation facilities and per capita income, per capita income and household conditions, and per capita income and household assets were also obtained to test the validity of the hypotheses.

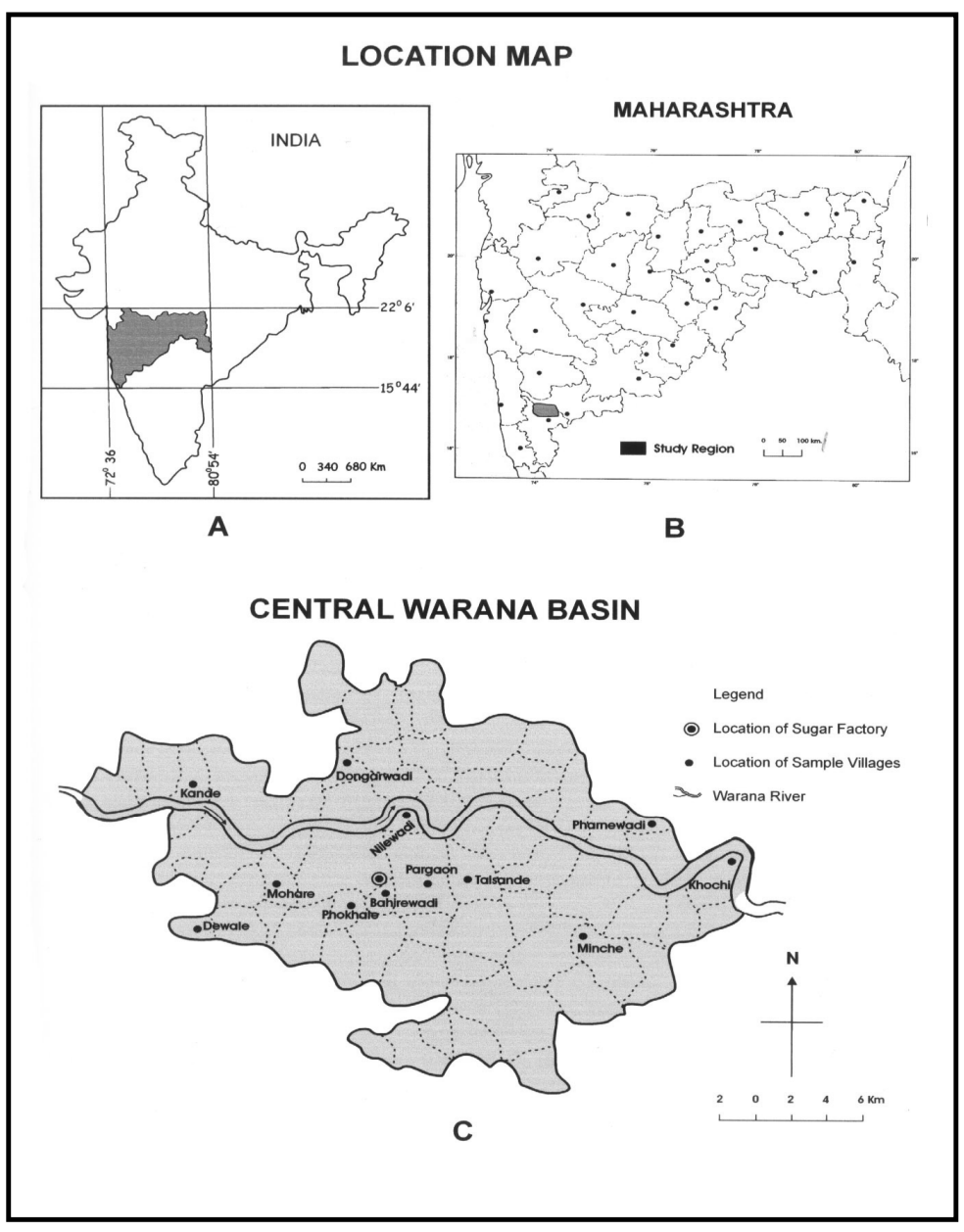

Figure 1 Map showing the study Area 


\section{Results and Discussion Literacy Rate}

The data presented in Table 1 revealed that the literacy rate varied from a minimum of 64.04 per cent in village Dongarwadi to a maximum 91.70 in Kande village. Similarly minimum female literacy rate ranged from $49.02 \%$ in Dewale village to a highest of $84.7 \%$ in village Kande. The village Dongarwadi is least developed due to its unfavourable physiography and low proportion of land under irrigation and Kande is one of the highly developed villages of the region due to its favourable terrain and location on the left bank of river Warana. The villages closer to the Warana complex are having high male as well as female literacy rates, it explicitly evidenced that they are highly benefited by the educational facilities provided by the Warana complex and the distant villages are less benefited in this regard.

\section{Levels of Educational Attainment}

Educational attainment is one of the important indicators of development that influences the level of prosperity largely. Warana complex has played a very important role in the educational development of the people in the region by opening different traditional as well as technical institutes at Warananagar and by giving grants generously for the construction of primary and middle schools in the region. This has certainly helped in attaining high level of education in the region. The villages closer to the complex like Mohare, Pokhale and Talsande have been highly benefited and have attained higher level of educational attainment. But some villages like Dewale and Dongarwadi have also made appreciable progress in this regard in spite of their unfavourable physiography and distant location from the complex. Adverse physical and climatic conditions have forced them to achieve higher level of educational attainment for the survival of the people in these two villages. Village Kande has attained higher progress in this regard due to conducive conditions. Other villages of the region have made moderate progress in educational attainment.

\section{Work Participation}

The proportion of persons engaged in any gainful activity is called as work participation rate which is one of the indices of economic development and differentials in it depend upon the male-female and rural-urban participation rates. Earning bread is still primarily a male responsibility in most of the societies of the world (Metha, 1967). There is more disparity in work participation in less developed countries due to sharper differences in the nature of social life and the economy in urban and rural areas (Chandana, 1996).

The study region depicts almost the same picture as seen in the other parts of rural areas of the country regarding the work participation. It is highest in the Pokhale village $(74.88 \%)$ and lowest in Minche village (52.94\%) where adverse physical condition, low irrigation and low per capita land, etc. are prevailing; so that a large proportion of people are under compulsion to work for earning their livelihood. Work participation is comparatively low or moderate in other villages of the study region.

Work Participation in Non-Agricultural Sector

High proportion of workers engaged in secondary and tertiary activities is a symbol of economic development and high degree of sophistication and a flowering of national prosperity (Trewartha, 1969). The entire world was predominantly engaged in primary activities before the industrial revolution. The practice of secondary and tertiary occupations on a large scale is only recent origin. Even today much of the less developed world is dominated by primary activities. Majority of the working population in India is predominantly engaged in primary activities and the study region is not an exception to this being a rural area where agriculture is the mainstay of the people.

People's participation in nonagricultural sectors has been steadily increasing in the study region after the establishment of Warana co-operative sugar factory. The sugar factory and its sister institutions have provided job opportunities to about 5500 people directly in the Warana cooperative complex. This has raised the participation of people in non-agriculture sectors considerably. Villages like Bahirewadi, Pargaon, Pokhale, Talsande located near the co-operative complex and are more benefited by it due to which the participation of the people in non-agricultural sectors is comparatively more in these villages. It is found that Pargaon is highly benefited as its participation rate in non-agriculture sector is highest (29.46 per cent) being its proximity to 
the complex. The distant villages from the complex are less benefited as the proportion of workers in non-agricultural sector is relatively less, for instance in Dongarwadi $(2.21 \%)$ in 2005-06.

\section{Area under Irrigation}

Development of irrigational facilities has positively augmented the prosperity of the agrarian regions. It has increased the agricultural production as well as production of the cash crops. As a result, it has become one of the important indicators of development and consequently high standard of living. The river Warana, after the construction of a dam at Chandoli in 1976, has become perennial and the leadership of the Warana co-operative sugar factory, Warananagar initiated 62 small co-operative lift irrigation schemes with the technical and financial support in different villages of the study region. As a result of this the area under irrigation in the region has increased by many folds. The cropped area under irrigation was less than 7 per cent in 1961 and in 2005-06 the entire cultivated area under irrigation in villages of Bahirewadi, Pargaon, Nilewadi, Pharnewadi, Khochi and Kande. It was also noticed that the area under irrigation in the villages like Dewale (18.10 per cent), Dongarwadi (21.25 per cent) and Minche (24.60 per cent) was relatively very less because of unfavourable terrain and ignorance.

\section{Household Condition}

Dwelling unit or a house is an important indicator of economic development. Quality of dwelling unit in any region shows the level of economic development of its owner (Ramotra, 1997). As the economic condition of man improves; he improves his dwelling unit, by having certain modern facilities in the house. There is a strong positive correlation between economic condition of man and qualitative spacious house (Eshwarappa, 2006). Rural people pay more attention to improve their agriculture, marriages of their children with the improvement in their economic condition and after that they pay attention to improve the status of their dwelling units (Ramotra, 2002). It has been found that there is positive correlation $(r=0.71)$ between per capita income and household condition in the study region. Positive change has taken place in the status of dwelling units after the establishment of Warana Co-operative sugar factory at Warananagar and the development of other cooperative sister units in the region. The Warana co-operative complex is having the strong bearing in bringing the fast development of the people in general and farmers in particular and consequently the quality of dwelling units in the region.

The status of a household can be examined by considering the various indices like per cent of pucca households, households with 3 rooms and above, households having latrine facility, households having Biogas/LPG, etc. After the improvement of the economic condition, rural people do not give top priority to improve their houses as is observed in urban regions; as a result percentage of strong and pucca houses is quite low in the villages. Farmers holding five (ha) or more land are having spacious and pucca houses but small and marginal farmers live in smaller and semi pucca or kacha houses. It is found that there is a positive co-rrelation $(r=0.60)$ between irrigation and per capita income. It has influenced largely the quality of dwelling units particularly in those villages having their cropped area under irrigation. Villages like Pargaon, Khochi, Nilewadi, Pharnewadi, Talsande and Bahirewadi have made considerable progress in the development of irrigation field by which more than 90 per cent of the total agricultural land in these villages is under irrigation. Therefore, more than 45 per cent of the total houses in these villages are found pucca.

Farming community requires comparatively big houses to keep their agricultural implements and food grains besides their own accomodation. It has been observed during the field survey that majority of the households in the sample villages were with three and more rooms. The villages like Bahirewadi, Pokhale, Pargaon, Mohare, Nilewadi, Minche, Kande, Khochi, Dewale and Pharnewadi are characterised by three or more room houses. More than $80 \%$ households in these villages having three or more than three room houses. Comparatively low percentage of this kind of houses has been found in the villages like Dongarwadi (57.50 per cent) and Minche (65 per cent), because of low agricultural production due to inadequate irrigation facilities.

Basic amenities like latrine and Gobar gas/LPG are also essential for rural community 
since they are influencing health and hygiene of the people considerably. Besides, these two facilities are more helpful in keeping the balance of the environment. Realising the importance of Gobar gas that does not pollute the environment, the leadership of the Warana co-operative sugar factory encourged the member farmers of the factory to construct Gobar gas for which subsidy was provided by the factory. It certainly benefited the farming community to construct Gobargas plants and latrines. Hence, majority of households is having latrine facility in the study region. All the households in the village Bahirewadi are having latrine facility. It has been observed that most of the households in the sample villages are having latrine facility. The villages with high proportion of latrine facility are Kande (97.50\%), Pargaon (87.50\%), Mohare (87.50\%), Nilewadi (85.71\%), Khochi $(82.50 \%)$, Pharnewadi (80\%), Dewale $(80 \%)$, Pokhale (75\%), Talsande (75\%), Minche (50\%) and Dongarwadi (30\%), The last two villages have not been much benefited due to their geographical location and low proportion of their land under irrigation, hence, remained relatively less developed.

It is further found that village Khochi tops the list in the modern facilities having LPG in 57.50 per cent households. Village, Pargaon ranks second as (55 per cent) of the households are having this facility. It is followed by Talsande (45 per cent), Kande (42.50 per cent), Pokhale (42.50 per cent), Bahirewadi (32.43 per cent), Dewale (25 per cent), Pharnewadi (25 per cent), Mohare (22.50 per cent), Nilewadi (17.14 per cent), Minche (10 per cent) and Dongarwadi (10 per cent). This kind of pattern reflecting a very sharp inequality in possessing the LPG/Gobar gas. Here again the closer villages to the cooperative complex are found more benefited as compared to the distant villages that are less benefited. Traditional fuels like wood and dry cakes of cow dung are generally used for cooking purposes in the rural areas than that of LPG or Gobar gas.

\section{Land holders having more than $\mathbf{2}$ ha land}

Possession or ownership of land of two or more than two ha is an indicator of economic status of a household. This much land with irrigation facility is sufficient for a small family of four persons to get its livelihood. Unfortunately, with rapid rate of population growth, in our country, the per capita land has been becoming so small and the survival of the family has become difficult. The declination of land per capita in the state of Maharashtra has already been witnessed. It also holds true in the area under study also the proportion of landholders with 2 ha or more land is quite low. Village Khochi ranks first in this regard. 37.50 per cent of the total families of this village are owning 2 ha or more land followed by Kande 35 per cent, Bahirewadi 32.43 per cent and Talsande 27.50 per cent. The proportion of households having 2 ha or more land in other villages is found low. Village Mohare's share in this regard is lowest (7.50 per cent). Villages like Dongarwadi (10.00 per cent), Pharnewadi (12.50 per cent) and Nilewadi (14.39 per cent) families are getting their livelihood from small pieces of land. Therefore, the economic development in these villages is quite low and it is comparatively more in the villages where percentage of land ownership is somewhat better.

\section{Household Assets}

One can consider the household assets like TV, two-wheeler, telephone, car, refrigerator, etc. but in the present study we have considered Telephone and two-wheelers as important indicators in the countryside. These two indicators are enough to understand the state of household. Telephone shows communication level while two-wheeler is an important asset of mobility in the rural areas. Before the establishment of the Warana cooperative sugar factory these assets were practically unseen in the households of this region but now they are seen in quite considerable number. The villages closer to the Warana complex are more developed and are having more percentage of households with these two assets. There are 67.57 per cent of the total households with telephone facility and 81.01 per cent households with two wheelers in the village Bahirewadi. It is followed by Pargaon with 67.50 households having telephone facility and 77.50 per cent households with two wheelers. More developed villages like Khochi, Talsande and Kande come next with 75 per cent households having telephone facility and 67.50 per cent with two wheelers, 62.50 per cent households with telephone facility and 75 per cent households with two wheelers and 55 per cent households with telephone facility and 70 per cent households with two wheelers 
respectively. Village Dongarwadi falls at the bottom of the list in household assets. Only 10 per cent households of this village are having telephone facility and 20 per cent households with two wheelers. Villages like Dewale, Minche and Pharnewadi are placed at slightly better position than that of Dongarwadi. All these villages are located at the distance of 15$20 \mathrm{~km}$ from the Warana co-operative complex and are comparatively less benefited from it; therefore possession of these assets in these villages is found less. Other villages like Pokhale, Mohare and Nilewadi, fall in moderate category of ownership of the household assets.

\section{Per Capita Income}

Per capita income is a very important indicator used to measure the level of economic development. The analysis of the data collected through field survey shows that there is a positive correlation between irrigational facilities and per capita income (0.60), per capita income and housing condition (0.71) and per capita income and household assets (0.67). The per capita income of the people in the study region has been increasing year by year with the development of various forms of economic activities. It is observed that the per capita income of the people in the study region has increased by about 100 times during the last 45 years.

The villages like Pargaon, Bahirewadi, Nilewadi, Talsande are highly developed in terms of economic opportunities. These villages are located at the distance of $5-10 \mathrm{~km}$ from the Warana co-operative complex and are highly benefited by the various activities run in the complex. The village Khochi, though located at the outskirts of the complex, is having more per capita income due to its location on the right bank of river Warana and availability of fertile soils. Village, Pargaon ranks first in all the villages of study region and its per capita income was Rs 36,100/- in the year 2005-06. Village Dongarwadi is economically less developed due its distant location from the co-operative complex, unfavourable physiographic conditions infertile soils and inadequate development of irrigational facilities. Consequently per capita income of the people of Dongarwadi was only Rs 9,325/- in the year 2005-06. Other villages of the study region are economically moderately developed and are moderately benefited by the cooperative complex.
Therefore, per capita income in these villages ranges between Rs 10,000/- and Rs 20,000/-. Table 1 depicts the per capita income in various sample villages of the study region in the year 2005.06.

The selected indices have been transformed into a single composite index for better understanding by employing David Smith's ' $Z$ ' score method. The results for each sample village are presented in Table 2. These villages are classified according to their ' $\mathrm{Z}$ ' score in different levels of standard of living as given below:

Table 3 depicts the standard of living of the sample villages of the study region. Villages like Khochi, Pargaon, Kande and Bahirewadi are grouped into high standard of living category. Pargaon and Bahirewadi are located at a distance of less than $5 \mathrm{~km}$ from the co-operative complex and are highly benefited by it in various ways. These two villages have availed highest number of job opportunities from the complex. Besides, both the village have attained 100 per cent irrigation and are agriculturally well placed. Villages like Khochi and Kande though located at the outskirts of the complex; and have been benefited due to conducive natural conditions. Plane topography, fertile soils and 100 per cent cropped area under irrigation because of their location on the bank of the river Warana. These are some of the crucial aspects which have brought prosperity in these villages.

Villages like Talsande, Mohare and Pokhale are situated at such a site where the spread effect of the complex is very strong. Over 60 per cent of the total agricultural land of these villages is under irrigation. Hence the agricultural yield is comparatively high and therefore having moderate standard of living. In the villages like Dewale and Pharnewadi, unfavourable location factor has caused low level of economic progress. For instance Dewale is an irrigationally less developed village where subsistence agriculture prevails. Soil is not that fertile. These are some of the factors, which are responsible for the low standard of living. Pharnewadi though located on the bank of river Warana; the proportion of suitable agricultural land is scarce. More over proportion of people in non agricultural sector (9.59 per cent) was also comparatively less which has attributed to its low level of standard of living. 
The villages like Nilewadi, Minche and Dongarwadi are belonging to very low standard of living. Low female literacy, low participation rate in non-agricultural sector, low educational attainment and less availability of cultivable land are the main factors responsible for very low standard of living in the village Nilewadi. Villages like Minche and Dongarwadi are naturally unfortunate with undulating terrain, infertile soils, inadequate irrigation facilities, dominance of subsistance agriculture and lowest participation in non-agricultural sector have pushed these two villages into the last category.

\section{Conclusion}

According to the opinion of experts, the co-operative sugar factories have not been able to reduce inequalities in income and wealth, between the rich and the poor in fact the gap has augmented. It would be unrealistic to expect that the co-operative sugar factories should have reduced inequalities. The main reason of inequality is the unequal ownership of land and this can not be changed by the sugar factories. The Warana sugar factory, with its sister institutions has certainly reduced poverty, unemployment and inequality by providing employment opportunities to the people in its command area even beyond that. Because of this industrial complex the prosperity can be observed with evidences by looking at their way of life and housing condition which were existing before the establishment of sugar factory in 1959, now it does not. This kind of improvement in the standard of living is due to industrial location and its development which can be seen from any angle in its surrounding area. The villages which are near to the complex are benefited as compared to the distant villages that what is distant decay turned to be true. But the villages which are away from the industrial complex left with comparatively less benefitted should be addressed with priority to bring them at per with the advanced villages in the Warana region.

\section{References}

Chandna, R.C., (1996), A Population Geography Kalyani Publishers, Ludhiana, pp. 216-217.

Eswarppa, P., Krishnaiah, K. and Ramanaiah, Y.V.,(2006), "Socio-Economic Characteristics of Slum

Households in Tirupati Town,” Indian Journal of Regional Science, Vo.XXXVIII, No.1, pp.65-72.

Metha, S. (1967), “India's Rural Female Working Force and its Occupational Structure - A Geographical Analysis." The Indian Geographer, Vol. 12 Nos. 1 \& 2 p.50.

Ramotra, K.C., (1997), “Socio-Economic Status of Women in India and Maharashtra," The Indian Geographical Journal, 72(1), pp.39-44.

Ramotra, K.C., (2002), "Literacy and Educational Attainment in Ralegon Siddhi: An Appraisal," The

Deccan Geographer, Vol.38, No. 1,2 pp.17-30

Trewartha, G.J., (1969), A Geography of Population: World Patterns, Johnwiley \& Sons, New York, pp-171-173. 


\section{Table1-PARAMETERWISE CONDITION OF VILLAGES IN CENTRAL WARANA BASIN : 2005-06}

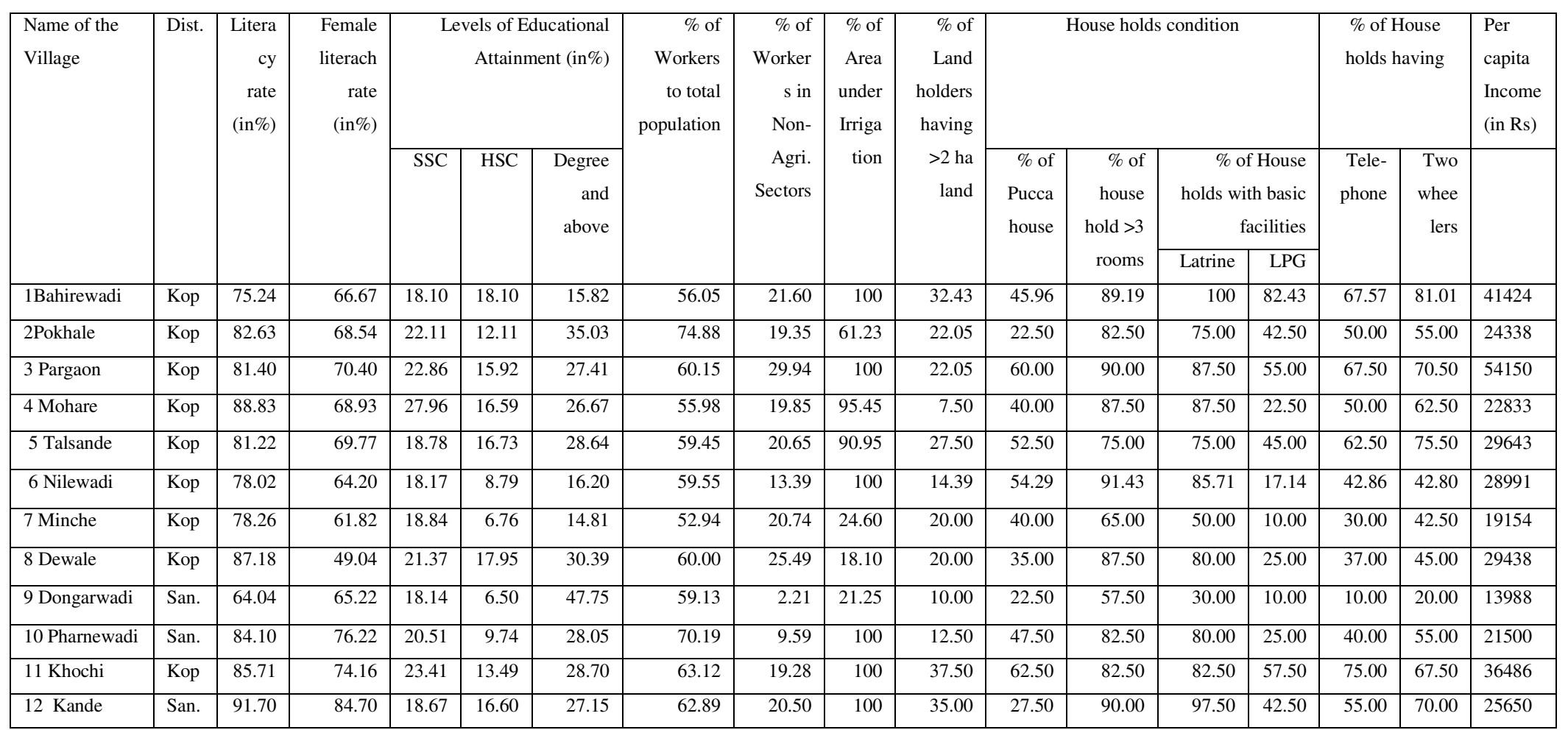

Source : Field survey 2005:2006 
Table 2- Parameterwise Condition of Village: 2005-06

\begin{tabular}{|c|c|c|c|c|c|c|c|c|c|c|c|c|c|c|c|c|c|c|c|c|}
\hline \multirow{3}{*}{$\begin{array}{l}\text { Sr. } \\
\text { No } \\
\text {. }\end{array}$} & \multirow[t]{3}{*}{$\begin{array}{l}\text { Name of } \\
\text { Village }\end{array}$} & \multirow[t]{3}{*}{ Dist } & \multirow{3}{*}{$\begin{array}{l}\text { Lite } \\
\text { racy } \\
\text { Rate }\end{array}$} & \multirow{3}{*}{$\begin{array}{l}\text { Fem } \\
\text { ale } \\
\text { Lite } \\
\text { racy } \\
\text { Rate }\end{array}$} & \multicolumn{3}{|c|}{$\begin{array}{l}\text { Level of Educational } \\
\text { Attainment }\end{array}$} & \multirow{3}{*}{$\begin{array}{l}\text { Wor } \\
\mathrm{k} \\
\text { parti } \\
\text { cipa } \\
\text { tion } \\
\text { to } \\
\text { total } \\
\text { pop } \\
\text { ulati } \\
\text { on }\end{array}$} & \multirow{3}{*}{$\begin{array}{l}\text { Work } \\
\text { ers in } \\
\text { Non- } \\
\text { Agri. } \\
\text { Secto } \\
\mathrm{r} \\
\%\end{array}$} & \multirow{3}{*}{$\begin{array}{l}\text { Are } \\
\text { a } \\
\text { und } \\
\text { er } \\
\text { Irrig } \\
\text { atio } \\
\text { n } \\
\%\end{array}$} & \multirow{3}{*}{$\begin{array}{l}\text { Land } \\
\text { holde } \\
\text { rs } \\
\text { havin } \\
\mathrm{g}>2 \\
\text { ha } \\
\text { land }\end{array}$} & \multicolumn{4}{|c|}{ Household condition } & \multicolumn{2}{|c|}{$\begin{array}{l}\text { Household } \\
\text { having }\end{array}$} & \multirow{3}{*}{$\begin{array}{l}\text { Per } \\
\text { Capita } \\
\text { Incom } \\
\mathrm{e}\end{array}$} & \multirow[t]{3}{*}{$\begin{array}{l}\text { 'Z' } \\
\text { Scor } \\
\text { e }\end{array}$} & \multirow{3}{*}{$\begin{array}{l}\text { Level } \\
\text { of } \\
\text { Stand } \\
\text { ard } \\
\text { of } \\
\text { Livin } \\
\mathrm{g}\end{array}$} \\
\hline & & & & & \multirow[t]{2}{*}{ SSC } & \multirow[t]{2}{*}{$\begin{array}{l}\mathrm{HS} \\
\mathrm{C}\end{array}$} & \multirow[t]{2}{*}{$\begin{array}{l}\text { Degre } \\
\text { e and } \\
\text { above }\end{array}$} & & & & & \multirow{2}{*}{\begin{tabular}{|l|}
$\%$ of \\
Pucc \\
a \\
house
\end{tabular}} & \multirow{2}{*}{$\begin{array}{l}\% \text { of } \\
\text { Hous } \\
\mathrm{e} \\
\text { holds } \\
>3 \\
\text { room } \\
\mathrm{s}\end{array}$} & \multicolumn{2}{|c|}{$\begin{array}{l}\% \text { of House } \\
\text { holds with } \\
\text { basic facilities }\end{array}$} & \multirow{2}{*}{$\begin{array}{l}\text { Tele } \\
- \\
\text { phon } \\
\mathrm{e} \\
\%\end{array}$} & \multirow{2}{*}{$\begin{array}{l}\text { Two } \\
\text { Wheele } \\
\text { rs } \\
\%\end{array}$} & & & \\
\hline & & & & & & & & & & & & & & $\begin{array}{l}\text { Latrin } \\
\mathrm{e}\end{array}$ & LPG & & & & & \\
\hline 1. & Bahirewadi & Kop & $\overline{0}-90$ & $\overline{0}-20$ & $\overline{0}-92$ & 1.15 & -1.31 & $\overline{0}-88$ & 0.44 & 0.86 & 1.14 & 0.26 & 0.73 & 1.19 & 0.02 & 1.06 & 1.35 & 1.05 & 6.29 & High \\
\hline 2. & Pokhale & Kop & 0.16 & 0.02 & 0.48 & $\begin{array}{l}- \\
0.27\end{array}$ & 0.90 & 2.34 & 0.12 & $\overline{0}-20$ & 0.03 & -1.52 & 0.08 & $\begin{array}{l}-0.14 \\
\end{array}$ & 0.76 & 0.06 & -0.16 & 0.86 & 2.40 & Mod. \\
\hline 3. & Pargaon & Kop & $\overline{0}-\overline{0}$ & 0.25 & 0.74 & 0.63 & 0.02 & $\overline{0}-18$ & 1.64 & 0.14 & 0.03 & 1.33 & 0.81 & 0.53 & 1.46 & 1.05 & 1.14 & 2.25 & $\begin{array}{l}13.1 \\
0\end{array}$ & High \\
\hline 4. & Mohare & Kop & 1.02 & 0.07 & 2.52 & 0.79 & -0.06 & $\overline{0}-89$ & 0.19 & $\overline{0}-44$ & -1.52 & 0.19 & 0.56 & 0.53 & -0.61 & 0.06 & 0.27 & -0.69 & 0.59 & Mod. \\
\hline 5. & Talsande & Kop & $\overline{0}-04$ & 0.17 & $\begin{array}{l}- \\
0.68\end{array}$ & 0.83 & 0.16 & $\begin{array}{l}- \\
0.31\end{array}$ & 0.30 & 1.40 & 0.61 & 0.76 & -0.65 & -0.14 & 0.83 & 0.77 & 1.00 & -0.05 & 3.93 & Mod \\
\hline 6. & Nilewadi & Kop & $\overline{-}-50$ & $\overline{-}-50$ & $\begin{array}{l}-91 \\
0.91\end{array}$ & $\begin{array}{l} \\
\end{array}$ & -1.27 & $\overline{-}-28$ & -0.74 & $\overline{-}-62$ & -0.78 & 0.89 & 0.95 & +0.43 & -0.95 & 0.35 & -0.87 & -0.12 & $\begin{array}{l} \\
6.17 \\
\end{array}$ & $\begin{array}{l}\text { V.Lo } \\
\mathrm{w}\end{array}$ \\
\hline 7. & Minche & Kop & $\overline{0} .47$ & $\overline{-} .79$ & $\overline{-} .66$ & 1.53 & -1.43 & $\overline{-} .41$ & 0.32 & $\overline{-}$ & -0.19 & -0.19 & -1.80 & -1.47 & -1.41 & 1.08 & -0.89 & -1.04 & $\begin{array}{l}- \\
15.8 \\
2\end{array}$ & $\begin{array}{l}\text { V.Lo } \\
\text { w }\end{array}$ \\
\hline 8. & Dewale & Kop & 0.82 & $\overline{2} .33$ & 0.22 & 1.11 & 0.37 & $\begin{array}{l}- \\
0.20\end{array}$ & 1.00 & $\begin{array}{l}- \\
1.65\end{array}$ & -0.19 & -0.57 & 0.56 & 0.13 & -0.45 & $\begin{array}{l}- \\
6.08\end{array}$ & -0.74 & -0.07 & $-\overline{2.95}$ & Low \\
\hline 9. & $\begin{array}{l}\text { Dongarwa } \\
\text { di }\end{array}$ & San. & $\overline{-} .51$ & $\overline{-}-38$ & $\overline{-} .91$ & 1.70 & 2.37 & $\overline{-} .35$ & -2.36 & $\begin{array}{l}- \\
1.09\end{array}$ & -1.25 & -1.52 & -2.36 & -2.53 & -1.41 & $\overline{2} .21$ & -2.20 & -1.52 & $\begin{array}{l}- \\
23.2 \\
8 \\
\end{array}$ & $\begin{array}{l}\text { V.Lo } \\
\mathrm{w}\end{array}$ \\
\hline 10. & $\begin{array}{l}\text { Pharnewad } \\
\text { i }\end{array}$ & San. & 0.37 & 1.01 & $\begin{array}{l}- \\
0.08 \\
\end{array}$ & $\overline{-}-83$ & 0.10 & 1.54 & -1.29 & $\begin{array}{l} \\
\end{array}$ & -0.98 & 0.38 & 0.08 & 0.13 & -0.45 & $\begin{array}{l}-51 \\
\end{array}$ & -0.16 & -0.82 & $-\overline{2}$ & Low \\
\hline 11. & Khochi & Kop & 0.60 & 0.72 & 0.93 & 0.06 & 0.17 & 4.33 & 0.11 & 2.01 & 1.68 & 1.52 & 0.08 & 0.26 & 1.62 & 1.48 & 0.56 & 0.59 & $\begin{array}{l}13.9 \\
8 \\
\end{array}$ & High \\
\hline 12. & Kande & San. & 1.47 & 1.97 & $\overline{-}-72$ & 0.80 & -0.01 & 4.29 & 0.28 & 0.57 & 1.41 & -1.14 & 0.81 & 1.06 & 0.67 & 0.34 & 0.71 & -0.43 & 9.33 & High \\
\hline
\end{tabular}

Source : Field survey 2005:2006 
Table 3

Villages and their Standard of Living, 2005-06

\begin{tabular}{|c|l|l|c|}
\hline $\begin{array}{c}\text { Sr. } \\
\text { No. }\end{array}$ & 'Z' score & Villages & $\begin{array}{c}\text { Category of standard } \\
\text { of living }\end{array}$ \\
\hline 1. & $>5$ & $\begin{array}{l}\text { Khochi, Pargaon, Kande } \\
\text { and Bahirewadi }\end{array}$ & High \\
\hline 2. & O to 4.99 & $\begin{array}{l}\text { Talsande, Mohare and } \\
\text { Pokhale }\end{array}$ & Moderate \\
\hline 3. & 0 to -4.99 & Dewale, Pharnewadi & Low Low \\
\hline 4. & $\begin{array}{l}\text { Less than }- \\
\text { Nilewadi, Minche and } \\
\text { Dongarwadi }\end{array}$ \\
\hline
\end{tabular}

Source: Field Work 2005-06. 